\title{
Relational integration: a response to Willem Schinkel
}

\author{
Lea M. Klarenbeek@
}

Correspondence:

L.M.Klarenbeek@uva.nl

This Commentary is an excerpt of a

chapter of my dissertation.

Department of Political Science,

University of Amsterdam,

Amsterdam $1001 \mathrm{NB}$, The

Netherlands

\begin{abstract}
In this essay, I respond to Schinkel's recent statement that 'any claim and practice that concerns 'integration' should be the object of research, rather than the project of research' $(2018$, p. 8). Although I agree with Schinkel that there are problematic practices of integration research, I do not agree that integration cannot be used as an analytical concept with heuristic value. In his critical analysis of how 'integration' is (ab)used as a political project, Schinkel seems to claim that there is no way to think of integration outside this problematic discourse. I argue that the concept of relational integration enables us to do just that by solving the most fundamental conundrum presented in his critique: that the concept of integration exempts 'nonmigrants', and places migrants outside society.
\end{abstract}

Keywords: Relational integration, Relational equality, Integration research, Power

\section{Introduction}

In the last decade, Willem Schinkel has published a collection of scholarly works analyzing the ways in which the concept of 'integration' is (ab)used in both political discourse and social scientific research $(2010,2013,2017,2018)$. I agree with Schinkel that conceptualizations and operationalizations of integration can be problematic and that a critical analysis of such research practices is important. As Schinkel puts it: social science provides the 'factual architecture' within which problematizations around integration take shape (2018, p. 2). Hence, being reflexive in the use of our concepts and measurements is vital both for epistemic reasons (we want to do good research) and non-epistemic reasons (we need to be conscious of the effects of our research, beyond the knowledge we produce).

Yet, Schinkel seems to rule out any possibility in which 'integration' can be used as an analytical tool to help us understand situations and phenomena that emerge after immigration. In his view, there is no 'right' way of conducting integration research: 'integration' functions as a neoliberal and neocolonial project. As such, it serves to govern diversity and monitor Otherness, and reinforces a discourse of the normalcy, superiority, and privileges of the 'white, enlightened, progressive, Western citizen'. Schinkel suggests that any research on integration inherently reproduces these connotations. Integration is therefore not to be understood as something normatively desirable, and nor can it be researched in a descriptive way.

I argue that this is throwing out the baby with the bathwater. As a potential solution to the problems Schinkel diagnoses, I introduce the concept of relational integration,

(c) The Author(s). 2019 Open Access This article is distributed under the terms of the Creative Commons Attribution 4.0 International License (http://creativecommons.org/licenses/by/4.0/), which permits unrestricted use, distribution, and reproduction in any medium, provided you give appropriate credit to the original author(s) and the source, provide a link to the Creative Commons license, and indicate if changes were made. 
which enables us to both conduct empirical investigation into people and institutions in post-immigration contexts ('post' here meaning 'after', not 'beyond'), and critically reflect on the (ab)use of the concept of 'integration' and 'society', because the latter is an inherent part of the former. To use Schinkel's terms: relational integration makes 'integration, as an object, part of the project of integration research.

\section{'Integration dispensation'}

Schinkel starts his analysis from the observation that there is a tendency to uphold and reproduce a distinction between 'people who need to integrate', and 'people for whom integration is not an issue' (2018, p. 5). This is, indeed, a manifest trend in the field. ${ }^{1}$ The research most vulnerable to Schinkel's critique is that in which integration is understood although rarely explicitly defined - somewhere along the lines of immigrants scoring equal to non-immigrants (on indicators such as employment, income, or educational attainment). Integration is then, mostly quantitatively, measured by comparing the average attainments of a certain category of immigrants to the average attainment of the non-immigrant. Subsequently, differences between these categories, with the 'immigrant' categories often being worse off, signify an integration problem for the immigrant, which, as Schinkel rightly points out, is not just a descriptive category but intersects with class, gender, and race.

As such, integration is mostly conceptualized as a process that only immigrants go through. ${ }^{2}$ This is not to say that such analysis ignores the existence of the receiving society altogether: most research acknowledges change in the receiving society as a consequence of integration, and addresses the either impeding or facilitating influence it can have on immigrants' integration process. However, non-immigrants are not conceived as agents who integrate themselves. So whereas integration outcomes may be explained by the institutions, attitudes, or conduct of the host society, it is not measured through these indicators. Integration thereby remains, essentially, a one-way process (Klarenbeek, manuscript submitted for publication).

This operationalization, Schinkel shows, triggers a number of problems, the most prominent being what he calls the 'dispensation from integration' for the non-immigrant (2018, p. 6). Because non-immigrants are used as the benchmark for comparisons within integration research, they are themselves absolved of having any integration problems. Further, he adds the critique of 'deindividualized individualization' (2017, p. 30), which concerns the paradoxical ways in which immigrants are both conceived as individuals who can be more or less integrated than others on an individual level, while also being monitored for the integration of an immigrant category as a whole. So even when an immigrant is well-integrated individually, (s)he may still be part of the statistics showing that 'the majority of immigrant category X' has an integration problem.

In doing so, such research practices resonate with, and risk reinforcing, the increasingly dominant political discourse of 'civic integrationism' (see e.g. Lentin \& Titley, 2011). ${ }^{3}$ This discourse locates the responsibility for integration with the immigrant, and portrays 'the national society' as a harmonious whole without any integration problems. This is problematic, firstly because such a harmonious society does not exist, and thereby does not provide a good analytical category to base research on (see e.g. Joppke \& Morawska 2003). Secondly, if the goal of integration is for outsiders to become part of an already integrated community, we risk attributing this society a prescriptive character. Rather than a description of an assemblage of social life in all its diversity, it 
becomes a concept which prescribes a dominant norm of what the social life should be (Schinkel, 2018, p. 7). The 'non-integrated' are not yet part of this society because they lack certain characteristics that are needed to adhere to this norm (e.g. relationships with the non-immigrant, endorsing certain values, certain amounts of human capital, etc.). Integration then becomes a process for 'deviant' people, who need to overcome their deficiencies (Kostakopoulou, 2010, p. 946). Such assumptions of what is 'normal' in society can have stigmatizing and marginalizing consequences. Thirdly, the logic of 'integration dispensation' risks eternalizing the boundary between 'the immigrant' and 'the non-immigrant'. When an immigrant does well, (s)he becomes a 'well-integrated immigrant, rather than receiving integration dispensation. In this way integration becomes, in the words of Horner and Weber (2011), 'a game that cannot be won'.

While several scholars have critically discussed the ways in which political and analytical conceptions of integration are conflated (Bommes \& Thränhardt, 2010; Favell, 2003; Scholten, Entzinger, Penninx, \& Verbeek, 2015), little structural attention has been paid to solutions to this problem. Schinkel's resolution seems to declare it impossible to use the concept outside of the discourse he criticizes. In his view, the sole task of social scientists is to investigate how this discourse functions: how 'society' is imagined, how 'difference' is constructed, and how the concept of 'integration' in fact produces an extra burden for immigrants (2017, p. 13).

Such critical analysis should, indeed, be part of relational integration research. Yet, we should not care about 'integration' merely as a political concept to be deconstructed. One of the inherent consequences of migration in the current global system with nation-states and their corresponding borders, citizenship regimes, and polities, is that people need to deal with perceived differences, questions of membership, and inequalities. ${ }^{4}$ In such contexts, inequalities in power innately emerge. This is true whether states interfere or not, whether media report on it or not, and whether scholars investigate it or not. Not researching integration does not solve such issues.

Further, to say that the current integration discourse creates and reiterates a discursive opposition between immigrants and non-immigrants is not to say that overcoming such oppositions is thereby logically or empirically impossible. Indeed, we know of historical cases, such as the Italian and Irish immigrants in the U.S., where immigrants have received 'integration dispensation' after having been regarded as highly problematic immigrants at first (see e.g. Alba, 2017).

\section{Relational integration}

When carefully conceptualized, 'integration' as an analytical concept can help us understand sociological processes of boundary maintenance and boundary change. Elizabeth Anderson's work on integration (2010) and relational equality (1999) provides a starting point here. Anderson's conception of integration concentrates on relational equality. Unlike frameworks of distributive equality, relational equality is not primarily concerned with the equal distribution of goods (material or immaterial) but rather with the relationships in which they are distributed (Anderson, 1999; Scheffler, 2003; Schemmel, 2012). ${ }^{5}$ Relational inequality emerges where power relations constitute superior and inferior positions that generate and justify inequalities in the distribution of freedoms, resources, and welfare (Anderson, 1999, p. 312). Relational equality demands that all members of a society: 1) acknowledge everyone's moral worth; 2) have equal social 
standing as moral agents; 3) are entitled to an equal chance to participate in the polity; and 4) that all perspectives and interests are weighed equally in processes of decision-making.

Following Anderson (2010), I argue that we should think about integration as constitutive of relational equality. I define relational integration as the process of boundary change towards more relational equality. ${ }^{6}$ It is, in a sense, the antonym of Weber's concept of social closure (Tilly, 2005; Weber, 1978), in which dominant groups exclude others from the specific forms of capital that sustain power differences between them. Relational integration does not primarily concern the decrease of objective difference, but rather the meaning of perceived difference. The two are not unrelated: they mutually affect each other. Yet, objective differences are not necessarily a problem for relational integration; they only become so if they are perceived as a reason to ascribe people lower or higher social standing.

Processes of relational integration revolve around whatever social boundary maintains relational inequality. Hence, they are not necessarily connected to issues of migration. (Anderson's own work on integration, for example, is concerned with racial integration in the U.S.). The most important social boundary for research of relational integration in post-immigration contexts is the one constructed around 'foreignness'. This boundary constitutes a distinction between 'legitimate' and 'non-legitimate members' of a society (the term legitimate here denoting a social construction of legitimacy, not legal status). Legitimate citizens are portrayed as 'real citizens', whereas the citizenship of 'non-legitimate citizens' is questioned. They are, in the civic integrationist discourse, marked as 'in need of integration' (see also Schinkel, 2010). This social boundary presents us with a problem of relational inequality: it affects the social standing of an immigrant as a moral agent (perceived as 'someone with foreign morals'), and as a participant (perceived as 'external interference in the polity'), and is thereby likely to affect the equal consideration of their perspectives, preferences, and interests in decision-making processes.

The idea of foreignness is not just a description of a legal 'migration status'. As many scholars have shown, the immigrant category intersects with race, gender, and class (see e.g. Bonjour \& Duyvendak, 2018; Korteweg \& Triadafilopoulos, 2013). Some immigrants are seen as more 'immigrant' than others. This is, for example, expressed in the difference between 'immigrant' and 'expat'-the latter tend to suffer less from the oppression of relational inequality than the former. Yet, legal status and the legitimacy of citizenship mutually influence each other. On the one hand, the legal status of citizenship offers opportunities to participate that are not available to people without this status. On the other hand, the conception of foreignness (and attached ideas of moral equality) is reflected in a state's border regime: it affects the rules for who is allowed to immigrate and who is seen as eligible for (future) citizenship.

Relational integration is not a 'neutral' concept, in the sense that it is stripped from its political or normative content (as e.g. Penninx and Garcés-Mascareñas (2016) have argued for). It is also not a descriptive term for a linear, mutual process of accommodation. Relational integration is one potential outcome of what happens when people deal with differences in a post-immigration context. However, it is not just any outcome, but rather a desirable outcome. Relational inequality is a form of injustice, first, because it constitutes oppression (Young, 2011): those of superior rank are 'thought entitled to 
inflict violence on inferiors, to exclude or segregate them from social life, to treat them with contempt, to force them to obey, work without reciprocation, and abandon their own cultures' (Anderson, 1999, p. 312). Second, relational inequality generates inequalities in the distribution of freedoms, resources, and welfare (Ibid.). Relational equality is therefore both intrinsically valuable, as a matter of social standing, and instrumentally valuable as a tool for distributive justice.

So to answer Schinkel's question: 'What added value does adding this second layer -integration'- on top of an observed differentiation in socio-economic positions have anyway?' (2018, p. 7), I argue that first of all we have a normative reason to investigate how relational integration is possible, and what the potential barriers are. Second, we have an epistemic reason. It may not be immediately clear why socioeconomic inequality should be seen as an integration problem as soon as people with an immigration background are involved. Yet, relational integration adds an analysis of the underlying structures of relational inequality through which socio-economic positions are constructed, maintained, and transformed. It therefore enables us to analyze practices of exclusion, social closure, and discrimination of people categorized as 'immigrant' within a society.

\section{Dealing with Schinkel's critique}

I end this commentary by showing how relational integration deals with three important problems as stipulated by Schinkel. Firstly, and crucially, relational integration does not grant 'integration dispensation' to 'non-immigrants'. Because it fundamentally concerns a changing power relationship, its primary focus is not on (categories of) individuals. Instead, it concerns the integration between different (categories of) people within a society of which they are all part. Thus, it does not make sense to speak of the relational integration of migrants into 'society'. By discussing something as a problem of relational integration, it is not the immigrant who is constructed as a problem, nor is the immigrant primarily held responsible for a solution. Similarly, when speaking of integration within a society, and between people, society is not portrayed as a normative standard that the immigrant has to live up to. In researching relational integration, one does not monitor difference or Otherness, but the ways in which people relate to each other, how difference or Otherness is constructed through institutions and symbols, and how this affects people. The power differential in defining 'who belongs', or 'whose citizenship is legitimate, is essential for this analysis. Hence, through this relational shift, we get rid of 'integration dispensation' and 'deindividualized individualization', thereby reducing the risk of feeding in to problematic political discourses of civic integrationism.

A second point to be discussed is Schinkel's critique of the use of the concept 'society'. For Schinkel, 'society' is a politically charged signifier which cannot be used as a basic category of social inquiry (2017, p. 220; 2018). Instead, we are to think of society as 'an active form of social imagination' (see also Anderson, 1991). Integration research, therefore, should not focus on the question of who is a legitimate part or member of this 'society', because it thereby inherently reproduces and reifies the highly politicized idea that there is such a thing as 'a society' with an in- and outside (2017, p. 222). In making this argument, Schinkel does not claim that society does not exist, but rather that it only exist as a fiction (2017, p. 20).

Again, Schinkel seems to argue that because 'society' is used as a politicized, discursive concept, we cannot use the concept in a different way. I agree that we should be 
aware of the ways in which 'society' is used as a fiction, and how this potentially affects relational integration. Social scientists should not reproduce the politicized idea that society is a well-functioning and harmonious whole that needs to be defended. Nor should society be used as a prescriptive standard that immigrants need to live up to in order to integrate. Yet, it makes sense to think of relational integration as a process taking place in the context of a collection of people who are all subject to the same rules of a polity. Most of these people will have formal citizenship, but not all. The provision and acquisition of national citizenship is an important part of the integration process. We could portray the 'national society' as a kind of Bourdieusian 'field' (Emirbayer \& Desmond, 2015), in which relational integration potentially takes place. This is not to say that it is the only relevant field: within and across the borders of the national society we find many other fields with their own integration dynamics. Yet, thinking of integration within current global institutions, one cannot dismiss the realities of national borders, polities, and citizenship regimes.

The third and last issue I address here is Schinkel's statement that we should avoid all language concerning in- and exclusion. A focus on exclusion, according to Schinkel, 'reifies the 'inside'; into which one can supposedly be included [ ...] What is possible is rather a differentiation in access to various forms of capital, a differentiation in positions, but such differentiations are - at least in the case of 'immigrant integration' never really 'exclusions' (2018, p. 8).

Nevertheless, as Schinkel also acknowledges (2017, p. 219), in- and exclusion are real in people's attitudes, behavior, experiences, perceptions, and consequences. It is exactly this 'social realness' that makes them important for social theory. Relational integration would not be concerned with exclusion from society, but with social closure within a society (see also Korteweg, 2017). Hence, it is exactly the differentiation in access to various forms of capital and positions that makes it so important to speak of exclusion. Moreover, the power to in- and exclude, to decide who is 'in' and who is 'out', is in itself an important form of capital (which can take either symbolic, cultural, economic, or political form). As such, the language of in- and exclusion provides a tool to analyze the 'gatekeeping power' (Alba \& Duyvendak, 2019; Jiménez, 2017) that some people have over others. When using the terms, however, we need to keep in mind that inclusion in a certain realm can simultaneously involve oppression (see also De Genova, Mezzadra, \& Pickles, 2015 for a conceptualization of differential inclusion). Hence, inclusion and relational integration are not synonyms.

Relational integration enables us to move past the deadlock between conventional approaches to integration and not researching integration at all. Taking Schinkel's critique on board, it has epistemic and non-epistemic advantages over both these options. For these advantages to be realized, it is critical that we implement this relational shift consistently in all stages of the research process.

\section{Endnotes}

${ }^{1}$ However, Schinkel's allegations require more nuance. He seems to take the worst reading of the worst practices of integration research as 'the academic field of integration research', and if he is aware of any positive exemptions to his accusations, he does not name them. Other than Schinkel, I actually see an increasing awareness that the role of the receiving society needs to be taken more seriously in measurements of 
integration For a more elaborate analysis of the extent to which different traditions in integration research reproduce this binary, see (Klarenbeek, manuscript submitted for publication).

${ }^{2}$ I want to mention two exceptions here: Crul and Schneider (2010) and Jiménez (2017).

${ }^{3}$ Note that this analysis is not (necessarily) about the intentions of scholars: the field tends to be rather critical of civic integrationism. Instead, it concerns the potential implications of the ways that integration is being researched. These implications do not stand on their own but come into being within the context of current political integration discourses.

${ }^{4} \mathrm{My}$ proposed framework of relational integration is a framework of non-ideal theory, aiming for a better understanding of integration within our current institutions.

${ }^{5}$ Distributive equality can be the outcome of just social relations, or unjust social relations which are then corrected (Schemmel, 2012). Distributive equality may be a condition for relational equality in some ways, and an outcome of it in others.

'It could be argued that it is not conceptually necessary to use the word 'integration'. One could speak of processes of boundary change towards relational equality without compromising the analytical potential of the framework. Nevertheless, I choose to stick with it in order to retain a connection to those research practices that focus on integration and that, in my view, need to be transformed.

\begin{abstract}
Acknowledgements
The author would like to thank Natalie Welfens for the stimulating conversations that have led to the writing of this article. Second, she thanks Richard Alba for the interesting discussions about practices of integration research as well as his insightful comments on earlier versions of the draft. She also thanks Floris Vermeulen, Anna Korteweg and Eric Schliesser for finding the time to read the manuscript and provide her with their very helpful comments. Last, she would like to thank the PhD-students at the CUNY Graduate Center immigration workshop for a chance to present the ideas and for a fruitful discussion afterwards, in particular Hiroyuki Shibata and Chris Maggio.
\end{abstract}

Funding

Not applicable.

Authors' contributions

The author is responsible for all the analysis and writing. The author read and approved the final manuscript.

Competing interests

The author declares that she has no competing interests.

\title{
Publisher's Note
}

Springer Nature remains neutral with regard to jurisdictional claims in published maps and institutional affiliations.

Received: 20 December 2018 Accepted: 11 February 2019

Published online: 15 May 2019

\section{References}

Alba, R. (2017). Continuities in assimilation. Ethnic and Racial Studies, 40(9), 1430-1437.

Alba, R., \& Duyvendak, J. W. (2019). What about the mainstream? Assimilation in super-diverse times. Ethnic and Racial Studies, 42(1), 105-124.

Anderson, B. (1991). Imagined communities. Reflections on the origin and spread of nationalism. London: Verso.

Anderson, E. (1999). What is the point of equality? Ethics, 109(2), 287-337.

Anderson, E. (2010). The imperative of integration. Princeton: Princeton University Press.

Bommes, M., \& Thränhardt, D. (Eds.) (2010). National paradigms of migration research. Göttingen: V \& R Unipress.

Bonjour, S., \& Duyvendak, J. W. (2018). The 'migrant with poor prospects': racialized intersections of class and culture in Dutch civic integration debates. Ethnic and Racial Studies, 41(5), 882-900.

Crul, M., \& Schneider, J. (2010). Comparative integration context theory: participation and belonging in new diverse European cities. Ethnic and Racial Studies, 33(7), 1249-1268.

De Genova, N., Mezzadra, S., \& Pickles, J. (2015). New keywords: migration and borders. Cultural Studies, 29(1), 55-87.

Emirbayer, M., \& Desmond, M. (2015). The racial order. Chicago: University of Chicago Press.

Favell, A. (2003). Integration nations: the nation-state and research on immigrants in Western Europe. Comparative Social Research, 22(1), 13-42. 
Horner, K., \& Weber, J.-J. (2011). Not playing the game: shifting patterns in the discourse of integration. Journal of Language and Politics, 10(2), 139-159.

Jiménez, T. R. (2017). The other side of assimilation. How immigrants are changing American life. Berkeley: University of California Press.

Joppke, C., \& Morawska, E. (2003). Integrating immigrants in liberal nation-states. Policies and practices. In C. Joppke, \& E. Morawska (Eds.), Toward assimilation and citizenship: immigrants in liberal nation-states, (pp. 1-35). London: Palgrave MacMillan.

Klarenbeek, L. (2018). Reconceptualizing 'Integration as a Two-Way Process'. Manuscript submitted for publication.

Korteweg, A. C. (2017). The failures of 'immigrant integration': the gendered racialized production of non-belonging. Migration Studies, 5(3), 428-444. https://doi.org/10.1093/migration/mnx025.

Korteweg, A. C., \& Triadafilopoulos, T. (2013). Gender, religion, and ethnicity: intersections and boundaries in immigrant integration policy making. Social Politics, 20(1), 109-136.

Kostakopoulou, D. (2010). The Anatomy of Civic Integration. The Modern Law Review, 73(6), 933-958. Retrieved from http:// www.jstor.org/stable/40926556

Lentin, A., \& Titley, G. (2011). The crises of multiculturalism. Racism in a neoliberal age. London: Zed Books.

Penninx, R., \& Garcés-Mascareñas, B. (2016). The concept of integration as an analytical tool and as a policy concept. In P. Rinus, \& B. Garcés-Mascareñas (Eds.), Integration processes and policies in Europe: contexts, levels and actors, (pp. 11-29). Springer, Cham. Retrieved from https://link.springer.com/chapter/10.1007/978-3-319-21674-4_2.

Scheffler, S. (2003). What is Egalitarianism? Philosophy and Public Affairs, 31(1), 5-39.

Schemmel, C. (2012). Distributive and relational equality. Politics, Philosophy and Economics, 11(2), 123-148.

Schinkel, W. (2010). The virtualization of citizenship. Critical Sociology, 36(2), 265-283.

Schinkel, W. (2013). The imagination of 'society' in measurements of immigrant integration. Ethnic and Racial Studies, 36(7), $1142-1161$.

Schinkel, W. (2017). Imagined societies. A critique of immigrant integration in Western Europe. Cambridge: Cambridge University Press.

Schinkel, W. (2018). Against 'immigrant integration': for an end to neocolonial knowledge production. Comparative Migration Studies, 6. https://doi.org/10.1186/s40878-018-0095-1.

Scholten, P., Entzinger, H., Penninx, R., \& Verbeek, S. (Eds.) (2015). Integrating Immigrants in Europe. Research-Policy Dialogues. Springer International Publishing. Retrieved from https://www.springer.com/gp/book/9783319162553.

Tilly, C. (2005). Identities, Boundaries \& Social Ties. New York: Routledge.

Weber, M. (1978). Economy and Society. An Outline of Intepretative Sociology. G. Roth \& C. Wittich (Eds.) (Trans.). Berkeley: University of California Press. Retrieved from https://www.amazon.com/Economy-Society-Outline-Interpretive-Sociology/ $\mathrm{dp} / 0520028244$

Young, I. M. (2011). Justice and the politics of difference. Princeton: Princeton University Press.

\section{Submit your manuscript to a SpringerOpen ${ }^{\circ}$ journal and benefit from:}

- Convenient online submission

- Rigorous peer review

- Open access: articles freely available online

- High visibility within the field

- Retaining the copyright to your article

Submit your next manuscript at $\boldsymbol{\nabla}$ springeropen.com 